\title{
Cold War Resurgence: The Case of Syrian Uprising
}

\author{
Dr Adigbuo Ebere Richard \\ adigbuo@delsu.edu.ng \\ Delta State University, PMB 1, Abraka. Delta State Nigeria
}

\begin{abstract}
Despite the appeals for a united and concerted action to resolve the armed conflict in Syria, the Security Council has failed to initiate actions that can ensure peace to the troubled country. This is principally due to the negative votes of some of the permanent members. The Syrian conflict and the behavior of the permanent members are reminiscent of the Cold War that featured a bipolar political rivalry between the United States and the Union of Soviet Socialist Republics. Two decades after the purportedly end of the Cold War, an unprecedented region-wide uprising began in the Arab world. Russia as the continuation of the former Soviet Union (although in different political and territorial terms), today defines its action in Syria in terms of its own national interests. The pursuit of such interests by these great powers has made Syria a theatre for high power diplomatic horse-trading reminiscent of the Cold War. This paper examines the manner the Syrian crisis is a semblance of the superpower rivalry of the Cold War years. The paper is suggestive of an imminent resurgence of another Cold War, should the major powers fail to sink their differences in Syria.
\end{abstract}

\section{Introduction}

Syria is a country in the Middle East, along the eastern shore of the Mediterranean Sea; historically, it has seen many invasions and occupations, from Romans and Mongols to Crusaders and Turks. The modern Syria gained its independence from France after WWII in 1946; the state has been associated with political instability ever since independence, due most probably to the conflicting interests of the political and military elites. From 1958-61 Syria was united with Nasser's Egypt, to form United Arab Republic. The union was dissolved in 1961; an army coup restored independence before the pan-Arab nationalist Baath (Renaissance) party took control in 1963. In 1969, Syrian politics involved a prolonged struggle for power throughout the early months of the year. The Syrian Army, under the defense minister, Lieutenant General Hafez al-Assad, took effective control of the government in order to force the Ba'athist Party (left-wing Arab Socialist) leadership to cooperate militarily with Egypt and Iraq against Israel. The following year, Hafez al-Assad seized control of his country's government as prime minister and became president in 1971. Assad ran a repressive government that sent thousands of troops to crush a Sunni political uprising in 1982. Assad and Sadat waged the 1973 Yom Kippur war against Israel and financed the Palestine Liberation Organization in its efforts to establish a Palestinian state. As his efforts to be aligned with Iraq failed in 1979, Assad supported Iran in its 1980-1988 war with Iraq. In 1991, he sent troops to fight against Saddam Hussein in the Gulf War. Syria has been ruled since 1963 by Alawites, a minority sect of Islam whose members include former President Hafez al-Assad and his son, President Bashar al-Assad. In this Syrian crisis under review, the Alawites are fighting to prop up Assad's regime. The concentration of power in the hands of the Assad family and their Alawite community had triggered protests among the Sunni-dominated rural areas, towns and cities, as opposed to other minority areas. Syria is sectarian.

The modern Syria is an artificial creation of the European colonizers; arbitrary borders were created by the imperial masters thus, forcing together an amalgam of diverse religious and ethnic groups. Thus Syria is currently a home to various ethnic and religious groups. The country's largest group is ethnic Arabs (53\%) who follow Sunni Islam, the leading sect of Islam. Next to the Sunni Muslims are the Alawites that are about 12 percent of the Syrian population; the Alawites are Shia'Muslims. The ethnic Kurds (5\%), long oppressed in Syria, have taken up arms against the regime. Other groups are Greek Orthodox Christian (10\%), ArmenianChristian (4\%), Arab-Druze (5\%), Arab-Ismaeli (2\%), and Turkmen, Circassian, Assyrian \& Jewish minorities $(1 \%){ }^{1}$

The ethno-religious composition of Syria has given rise to sentiments of sectarianism. The Sunni Muslims' fear is rooted in that both President Hafez al Assad and his son Bashar al-Assad are Alawites, the minority Shiites whom many Sunnis see as heretics and who had used their privileged position to corner the majority of cabinet and government positions. The Syrian government has not helped matters since it maintains a gang network known as shabiha, an armed militia group used to silence critics. Membership of shabiha is drawn from the Alawites. ${ }^{2}$ The support given to Assad by Shiite armies' points to sectarian motivations. Prominent in this reckoning are the interventions on the side of the Assad led government by the Shia Houthis 
that control parts of northern Yemen and its Lebanese counterpart Hezbollah. The backing of Iran further justifies these sectarian fears. The Sunni Muslim groups, especially Mustaqbal (Future), are allied to Saudi Arabia and sympathetic to Syria's Sunni rebels and the Sunni jihadis from around the region fighting on their side. $^{3}$

Some analysts have argued that the Syrian crisis is the inevitable re-balancing of power along ethnic and religious lines, with the Sunni Arab majority retaking control from the Alawite minority. The situation they postulate can be compared to post-2003 Iraq, when members of the Shiite majority violently took power from the Sunni minority that, under Saddam Hussein, had ruled them. That would explain why so much of the killing in Syria has been along sectarian lines. It would also suggest that there's not much anyone can do to end the killing because, this is a painful but unstoppable process. ${ }^{4}$

From the foregoing, it can be stated that the political power, long held by a small mainly Alawite elite, is being hotly contested in a civil war initially inspired by the Arab Spring. While the crisis soared, the United Nations, an international organization formed to maintain international peace and co-operation failed to intervene decisively. It was rather encumbered by endless debates and acrimonies reminiscent of the Cold War era. It is against this backdrop that this paper seeks to highlight the prosecution of the Syrian uprising in respect to its similarities with the politics of the Cold War. The Syrian conflict demonstrates that the end of the Cold War was proclaimed untimely. The international system is still engulfed in bipolarity in which Washington and Moscow (and, to a lesser extent, Beijing) continue to exert neocolonial influence through proxy states and regional spheres of influence. An unpretentious survey of the Cold War rivalry follows.

\section{The Cold War}

World War II fundamentally altered the distribution of global power. By the war's end Western Europe lay in self-afflicted ruin, with many areas destroyed for the second time in thirty years. Troops from two countries outside the region - the United States and the Soviet Union - had played decisive roles in defeating Germany. By taking the lead in developing nuclear weapons and the airborne to deliver them, the United States and the Soviet Union rose to global superpower status. ${ }^{5}$ The Cold War is descriptive of the 42-year (1949-1991) rivalry between the United States and the Soviet Union, as well as their competing coalitions, which sought to contain each other's expansion and win worldwide predominance. Certain situations gave each superpower reasons to struggle against the other's potential global leadership; that meant that each superpower sought to carve out and establish dominant influence in its own sphere of influence. As their relations deteriorated from wartime alliance to ideological and geostrategic rivalry, Europe and later the third world became theatres of the competition. The Cold War rivalry was carried into the United Nations, thus jeopardizing the prospects of maintaining peace and cooperation among nation-states. In the Security Council, more than 230 vetoes were cast, stopping action of any type on about one third of the UN's resolutions. In this period, UN action was only taken when a conflict was outside the East-West rivalry and did not involve either superpower. ${ }^{6}$ Holsti is of the view that between 1945 and 1984 the UN attempted to mediate only 40 percent of the 319 interstate conflicts that erupted. ${ }^{7}$ The Cold War rivalries were well-defined in the Middle East, a region the US and the West held with tenacity. In that rivalry, Syria elected to join the Soviet Axis. Soviet's interests in the Middle East during the Cold War might have resulted from the following: Moscow sought (1) to undermine Western influence; (2) to expand Soviet influence through exploitation of Arab Western and Arab-Israeli tensions; (3) to acquire a foothold in the Mediterranean, the Red Sea, and the Persian Gulf; (4) to disrupt Arab-Western oil relationship, with a view toward weakening Western Europe; and (5) to have a commanding voice in the management of Middle Eastern settlements, as befits the status of a superpower. ${ }^{8}$ On this note, the Soviet Union sought to undercut western dominance throughout the Middle East, an attempt which it began by strengthening ties with Egypt and Iraq. This was implemented by supporting both the Nasser-led Egyptian revolution in 1952 as well as the military coup d'état in Iraq that toppled Iraqi pro-West monarchy. ${ }^{9}$ The Syria-Soviet relationship was cemented between 1955 and 1960 when the Soviet Premier Nikita Khrushchev provided Syria with more than $\$ 200$ million in military aid to solidify the alliance and to counter U.S. influence in the region. ${ }^{10}$ When Egypt finally became a US ally just like Israel, Soviet Union had to strengthen its alliance with neighboring Syria in order to counter American influence in the area. ${ }^{11}$ Thereafter, with a reinforced Soviet-Syrian alliance, under a 1971 agreement, the Soviet Union built a naval supply and maintenance base in the Port of Tartus to support the Soviet Navy's fleet in the Mediterranean Sea. The Soviet Union also provided Syria with huge military assistance which Syria however complained were not as sophisticated as that provided by the United States to Israel. ${ }^{12}$ It must be appreciated that throughout the Cold War years, as Israel was to the United States, Syria remained the Soviet Union's favoured ally; that alliance accounts for the continued Soviet economic and military assistance to the country. ${ }^{13}$

The end of the Cold War ushered a New World Order with the U.S. enjoying a unipolar status. As part of exercising her new-found status, the United States began to intervene in conflicts beyond her borders without worries about Soviet opposition. She began by first intervening in Panama where its President, General Noriega 
was arrested for cocaine trafficking. Next, the United States intervened in the Persian Gulf War. ${ }^{14}$ Interventions continued to the Arab uprising, where with her NATO allies, the United States effected a regime change in Libya.

But the situation in Syria is different; the United States has failed to intervene despite her willingness to do so. NATO cannot intervene under the guise of the United Nations. Considering the international prosecution of the Syrian crisis alongside the major international players, some analysts suggest that the crisis is suggestive of a new Cold War. But how did the protests start?

\section{The Syrian Uprising}

Initially, while the Arab uprising spread elsewhere in the Middle East, some observers believed that Syria was particularly immune to the region-wide protests. This assumption was anchored on certain facts which included the perceived population's fear of sectarian violence coupled with the fact that Syria was a pervasive police state as well as the reforms which in Heydemann's view 'upgraded' authoritarianism in Syria. ${ }^{15}$ Even the Syrian President, Bashar al-Assad, shared the view of Syria's "exceptionalism" when he stated: "Syria is stable. Why? Because you have to be very closely linked to the beliefs of the people. This is the core issue." "16

Put differently, Syria is too stable to degenerate into a political turmoil. Syria had from the inception of the Baathist regime in 1963, maintained a nationalist foreign policy which is opposed to Western activities in the Arab world, particularly the activities of the United States in Iraq and Afghanistan. Syria also enjoys the support of Hezbollah and Hamas in confronting Israel. This is in contrast to Mubarak's Egypt and Ben Ali's Tunisia, both of which were Western allies. Syrian authorities assumed that the people favoured the anti Israeli/West stance; moreover, Syrians had a relatively young leader as distinct from the aging Ben Ali, Mubarak and Libya's Gaddafi. From these calculations, Syria was considered immune to the wave of unrests which blew across the Arab world.

However, by March 2011, contrary to all expectations, stability and calm had quickly evaporated into the thin air as chaos was to engulf Syria. In a wave identical to events in neighboring Tunisia and Egypt, thousands of Syrians poured into the country's major streets, demanding an end to the repressive Baathist regime of Bashar al-Assad. All the people wanted was democratization which would however exclude President Assad and his Baath party. What began as mere painting of anti-government graffiti had soon turned into popular protests, further degenerating into full-fledged civil war raging longer and with greater destructiveness than was initially ever anticipated.

The demands of the protesters included an end to emergency rule, the need for political reforms alongside the re-instatement of civil rights. One of the major sparks of the uprising in Syria occurred on March 6, 2011 when fifteen school children were arrested and tortured in the southern city of Dara'a for painting antigovernment graffiti on the walls of a school. ${ }^{17}$ Stunned and enraged by the treatment meted out on these Syrian students, hundreds of people took to the streets calling on the regime to put an end to widespread police brutality. When the government ignored these demands, the protesters reacted in exasperation, demanding an end to the Assad regime. ${ }^{18}$

The government responded by ordering a crackdown on the protesters. This resulted in the death of six protesters whose funeral procession on March 7, attracted some 20,000 people. Protests continued at the procession as Syrian security forces again cracked down on the protesters. ${ }^{19}$ News of events at Dara'a had sparked up further resentment against the government as the people began to demand an all-encompassing change in the scheme of affairs. Unwilling for any form of concession, the demands of the protesters had simply become an end to the regime, ${ }^{20}$ as it had become the belief among protesters that what was needful for sociopolitical development in Syria was regime change.

No sooner had the civil war started in Syria than reports of gross human rights abuse began to filter across the globe. The situation in Syria was basically characterized by mass protests, brutal police crackdown on protesters as well as armed rebellion from some of the protesters. Overwhelmed by the massive destruction of lives and properties in the lingering Syrian crisis, calls began to emerge from different quarters for a united and concerted action aimed at resolving the crisis. The protesters did not help matters, particularly as the rise in armed resistance has provided the Syrian regime with the excuses it needed to crush any opposition with bloodiest suppression. The armed resistance has largely taken the form of the Free Syrian Army, a varied force of defectors from Assad's armed services, as well as mercenaries and a bunch of uncompromising fundamentalists. Gradually, the domestic violence in Syria had worsened into a full-fledged civil war with wanton destruction of lives and properties.

Available data on the conflict shows that as at June 2012, an estimated 15,000 persons had lost their lives to the uprising. ${ }^{21}$ This number had however been tremendously multiplied by January 2013 as an estimated 120,000 people were believed to have died as a result of the uprising. ${ }^{22}$ Recent reports claim that the number of Syrian refugees in bordering countries total above two million. Burhan Ghalioun, a Syrian analyst declares that "there is no home in Syria without a missing father, a raped daughter, a detained young man or a violated 
child. ${ }^{, 23}$ As the civil war rages, rhetoric dominate the search for solution. Even the United Nations Security Council whose traditional role it is to restore order to a war-torn country has so far failed to reach an all embracing resolution. The United Nations Security Council has taken after the Cold War trend as would be shown shortly.

\section{Cold War Resurgence and the Syrian Uprising}

That the resounding echoes of war from the Syrian crisis have so far transcended the confines of her national boundary is not a matter under dispute. The emergence of several state and non-state actors in the conflict gives credence to this assertion. Nonetheless, an international scope to a conflict does not on its own suggest the resurgence of the Cold War. Indeed, other conflicts in the past such as the Persian Gulf War, the Iraq war among others had possessed international character in varying degrees but did not warrant suggestions of the likelihood of Cold War resurgence. It therefore becomes necessary to highlight the specific peculiarities of the Syrian crisis reminiscent of the Cold War before any deduction of resurgence.

One indispensable feature that played out in the outbreak of the Cold War was the emergence of a bipolar world from the ashes of World War II. The United States alongside the Soviet Union had become the globe's superpowers when all other contender-States had been crippled by the World War II. It was therefore these two States that championed the course of the Cold War. When the Soviet empire collapsed in 1991, the Cold War seemingly came to an end, prompting epithets like The End of History. Thus, it may become logical to assume that for the Cold War to re-emerge, the vacuum created by the disappearance of the Soviet Union must have been filled by either a new superpower or a number of superpowers as would be the case for a multipolar world.

On account of the foregoing and with specific regards to the Syrian conflict, Russia appears to have assumed a greater prominence than usual. This therefore raises the question as to whether Russia, somewhat as a continuation of the Soviet Union, possesses the necessary attributes to qualify as a superpower. Unfortunately, there is presently no scholarly consensus on what qualifies a state as a superpower so that assessing Russia's position as a superpower becomes tasking. Nonetheless, one must first begin with an understanding of the term "superpower" which in Flemes' view refers to "a state with the first rank in the international system and the ability to influence events and project power on a worldwide scale" ${ }^{24}$

Thus, for the sake of this study and for the purpose of clarity, certain key indicators of great or superpower status would be used to assess Russia's superpower position. These indicators include the economy, military capability as well as soft power capability. The choice of these three factors is influenced by their capability to sway events and project power on a worldwide scale. As regards economy, one must note how Russia has experienced periods of turmoil and impressive growth since the end of the Soviet Union in $1991 .{ }^{25}$ In the years following the implosion of the Soviet Union, Russia had experienced huge economic challenges. This was nonetheless followed by a period of boom in the years between 1999 and 2008. During this period, the country had experienced strong economic growth rate with an average increasing GDP of $6.9 \%$ per year. ${ }^{26}$

Russia's period of economic boom was followed by an economic downturn during the global economic meltdown when she witnessed a 7.9\% decline in 2009. The impact of the recession on Russia was deep but brief as she had bounced back on the path of growth by 2010. As of 2012 Russian GDP growth rate had clocked $3.4 \%$ while GDP per capita was $\$ 14,247$. In 2013 , the Russian population below poverty line was estimated at $11.2 \%$ a figure less than the percentage of unemployed Americans standing then over $14 \% .{ }^{27}$ Depending largely on natural resource exports particularly oil and gas alongside her military-industrial complex, the Russian economy ranks as the fifth largest economy in the world in terms of purchasing power parity (ppp). ${ }^{28}$ Moreover, abundant natural gas resource has earned Russia the recognition as an 'energy superpower'. But does an energy super-role status save an economy, some see, as struggling? As this paper is concluded, the United States and its European allies in July 2014 announced the imposition of stronger sanctions against Russia for meddling into the Ukraine crisis. Sanctions scare off investors and hurt the economy, and in particular the Russian economy that is dependent largely on oil and natural gas industry. The other sad aspect of these sanctions is that Russia is experiencing capital flight and its currency, the ruble, is losing value; sanctions also affect the Russian companies' access to foreign credits.

On military capability, some analysts advocate that it is imperative to first of all underline the fact that nuclear arms, both on a strategic and on a sub-strategic level, remain a priority for the Russian Federation. ${ }^{29}$ Despite a reduction of her nuclear arsenal, Russia with the second largest nuclear arsenal in the world, ${ }^{30}$ still maintains a second strike capability and as well retains a high defense capability against any nuclear attack. Cognizance of an appreciable Russian nuclear capability had recently precipitated the signing of the New Strategic Arms Reduction Treaty (New START) between the United States and Russia. The New START whose terms require further reduction and limitation of strategic offensive arms had been coined after the manner of the Cold War era STARTs I, II and III and was signed in April 2010. ${ }^{31}$ The arrangement therefore 
shows to what extent Russia is [and is accepted as] a successor of the defunct Soviet Union in the international arena.

More so, indications abound that the Russian armed forces number within an approximate range of one million. In recent times, an executive order has demanded that at least 70 percent of the Russian arsenal consist of modern weapons and equipment. Defense budget as of 2011 was $2.9 \%$ of the country's GDP and is expected to rise to $3.9 \%$ in $2014 .{ }^{32}$ Moreover, arms sales have also been a major source of funds for the country. All of these alongside an ever renewed commitment of the Russian leadership towards a strengthened military do indeed indicate the perception of Russia's superpower status. The foregoing assertion is reflected in a topical statement by President Vladimir Putin when he declared: "We [Russia] will do everything to strengthen security on the planet." 33

The third indicator of a superpower status as used in this study is soft power capability. Joseph Nye coined the term to mean the ability of a country to achieve its national goals by shaping the preference of others. ${ }^{34}$ In furtherance thereof, Tsygankov suggested that a state's soft power capability could be effectively measured through certain aspects of the state's attractiveness to foreigners, including the mass media, familiar language and religion, aspects of historical legacy, and electronic products, among others. ${ }^{35}$ In line with the foregoing, as regards the mass media, the government of the Russian Federation has created an English language 24/7 news network known as RT (Russian Today). With offices in Washington D.C. and elsewhere, RT now broadcasts Moscow's perspective of news to American audiences as well as in over 100 other countries, thus becoming the Russian version of BBC and CNN. ${ }^{36}$

On language and religion, the Russian language has continued to be a common language in social, business, scientific and cultural relations across post-Soviet states. Also, the Russian Orthodox Church despite the implosion of the Soviet Union has continued to wield a huge influence both in Eastern Europe and beyond. ${ }^{37}$ It has also become increasingly active in many international organizations while it has been consulted on a couple of socially delicate issues. It currently maintains an observer status at the Organization Islamic Countries and as well hosts international summits in Russia. Russia's Muslim component has also been used to identify with the Islamic world, a feat which gives Russia a better image with the Islamic world as opposed to the United States and its western allies. ${ }^{38}$ On historical legacy, one must understand Russia's influence in Eastern Europe; it was through her efforts that Soviet Union was constituted into a state of superpower status. Moreover, prior to the Soviet era, a powerful Russian Empire had as well wrapped up most of these neighboring nations under a unified leadership.

Thus, with the foregoing in mind, the point must be noted that the Russian federation has so far embarked on an active effort towards projecting her soft power across the globe. It does not at the moment lay claims to a superpower position but has projected itself a power to be reckoned with in the international arena. Therefore, as a notable power on the global stage and as a continuation of the Soviet Union, it becomes safe to perceive the imminent resurgence of a new Cold War, given the way and manner in which the Syrian uprising is being prosecuted.

As noted earlier, among the most prominent features of the Cold War years was the lack of unanimity among the five permanent members of the United Nations Security Council (UNSC). This situation had led to the failure of the UNSC to promptly resolve threats to international peace and security given the "veto rights of the great powers". This trend which had been drastically reduced in the post-Cold War years was however to reemerge in the course of the Syrian uprising when in particular, the United States and Russia, permanent members of the Security Council repeatedly failed to agree on certain key issues about the Syrian crisis.

On February 4, 2012, the hope for a United Nations Security Council resolution was dashed when Russia and China vetoed the Western-backed Arab resolution that called for the resignation of the Syrian President, Bashar Assad. ${ }^{39}$ This was repeated on July 19, 2012 when Russia and China again vetoed a U.N. Security Council resolution that threatened the Assad regime with sanctions if it would not end violence against the Syrian opposition groups. ${ }^{40}$ These were followed by warnings and threats from particularly Russia against Western intervention in the Syrian conflict. ${ }^{41}$ The implication of these is a continuance of the Cold War trend when mutual antagonism among great powers dominated the global politics.

The Syrian uprising could also be viewed from the lens of Cold War race for allies and spheres of influence. On this note, the clamor for military intervention in Syria as sponsored by the United States and its allies could be understood as a conscious effort to oust an unfriendly regime, as it happened in Libya. Russia has taken extra measures to forestall any military intervention in the Syrian crisis. Besides the fact that Syria has remained Russia's highest arms purchaser in the Middle East, she harbors Russia's only military facility in the Middle East at the Port of Tartus. ${ }^{42}$ Moreover, Russia's deployment of its most powerful warship and a spy vessel to the eastern Mediterranean to observe any U.S. operations against Syria reflects the worsening state of U.S.-Russian relations in the past few years and underscores lost opportunities for bilateral cooperation, analysts assert. ${ }^{43 / 53}$ Other Russian efforts that are reminiscent of the Cold War years are: 
- The deployment of Russian long-range bombers which occasionally test U.S. air defenses by flying close to Alaska, and have done so as recently as April, 2013.

- In May, Moscow publicly expelled a U.S. diplomat who it said was spying on Russia - three years after Washington uncovered a Russian spy ring and eventually sent 10 agents back to their motherland.

- Russia expressed outrage last year [2012] over NATO anti-missile defenses in Eastern Europe, saying the interceptors could be used against its own missiles.

- Moscow granted asylum to Edward Snowden, who is wanted by U.S. authorities for stealing and publishing details about the National Security Agency's top-secret data collection programs. ${ }^{44}$

Another basic feature of international politics during the Cold war years was the use of sanctions against antagonistic blocs. As early as 1948, the United States had begun a campaign of economic sanctions against the Soviet Union. Legalized with the Exports Control Act of 1949, exports to the Soviet Union and its European allies were restricted. ${ }^{45}$ A similar case was also noted in Asia where the United States placed embargo on China, North Korea and North Vietnam in 1950, during the Korean War. Similar and perhaps more stringent measures were also placed on Cuba, another Cold War enemy in 1959. While the Cold War raged, it must be noted that the United States placed economic sanctions on virtually all the countries that were in the Soviet bloc. $^{46}$

In the same vein, the outbreak of the Syrian crisis had marked increased imposition of economic sanctions. Though the United States had in 2004 slammed sanctions on Syria because of its support for 'terrorism', yet on August 17, 2011, further sanctions were introduced. The 2011 sanctions were facilitated through the U.S. Executive Order 13582. Since sanctions are an alternative to war, the Executive Order was meant achieve the following:

- Blocks all property and interests in property of the Government of Syria, which includes its agencies, instrumentalities and controlled entities, within U.S. jurisdiction, whether specifically identified by OFAC or not

- Prohibits U.S. persons from exporting or re-exporting services to Syria.

- Prohibits U.S. imports of Syrian-origin petroleum or petroleum products.

- Prohibits U.S. persons from having any dealings in or related to Syrian-origin petroleum or petroleum products.

- Prohibits U.S. persons, wherever located, from operating or investing in Syria.

- Prohibits U.S. persons from approving, financing, facilitating or guaranteeing transactions by foreign person where the transaction by that foreign person would be prohibited if performed by a U.S. person or within the U.S. ${ }^{47}$

More so, it would be recalled that during the Cold war, the United States provided aids (whether military or financial) to virtually all groups that stood in opposition to Soviet influence. For instance, when the Soviet Union attacked Afghanistan in 1979, the United States launched "Operation Cyclone" which was a Central Intelligence Agency program designed to arm and finance the Afghan Mujahideen against the Soviet Union. ${ }^{48}$ Interestingly, in the same manner, the United States has lent its support for the Syrian rebels against the Syrian regime. On December 11, 2012, the Obama administration announced that the United States would "formally recognize a coalition of Syrian opposition groups as that country's legitimate representative, in an attempt to intensify the pressure on President Bashar al-Assad to give up his nearly two-year bloody struggle to stay in power." ${ }^{, 9}$

Meanwhile, the U.S. has countered Russia's deployment of its most powerful warship and a spy vessel to the eastern Mediterranean. The U.S. military officials had announced they were deploying Patriot missiles and other U.S. military equipment and personnel in Jordan. The missiles were originally to be sent there as part of a joint U.S.-Jordanian military training exercise codenamed "Eager Lion," and were to be withdrawn upon completion. Now, it's been decided the missiles are to remain in Jordan alongside a deployment of F-16 fighter jets and an additional 200 "military planners" separate from the training exercise. U.S. Defense Secretary Chuck Hagel approved the change in plans, as a response to the worsening civil war inside neighboring Syria. Officials say they are there to assist with relief efforts for refugees from the war-torn Syria. ${ }^{50}$

Another salient feature of the Cold War that is being replicated in the Syrian uprising is the polarization of the world. As has been noted earlier, during the Cold War years, the world was essentially divided into two camps: the Eastern and Western blocs. The Soviet Union and its allies within and outside Europe represented the Communist bloc while the United States and its allies represented the Western bloc. There was however a third camp which neither supported the Eastern bloc nor the Western bloc: the non-aligned. This group chose not to concern themselves with the superpower and/or ideological rivalry between the Soviet Union and the United States. Prominent among this third group was India under President Nehru. Other Afro-Asian countries also belonged to the nonaligned group. 
In the same manner as it was in terms of polarization during the Cold War years, the Syrian uprising had as well polarized the world into two different camps. A third camp as well exists which has chosen to be rather neutral in the Syrian affair, as was the case with the Non-Aligned Movement during the Cold War. The United States assumed leadership of the "Western camp" which repeatedly pledged support for the Syrian opposition. Members of this camp make up the group known as the "Friends of Syria Group." The Friends of Syria Group is an international effort by countries and bodies convening periodically on the topic of Syria. Over seventy countries are involved; representatives are also drawn from the Arab League, African Union as well as European Union. ${ }^{51}$

While the Friends of Syria Group appears to be the Western bloc of the "new Cold War", Russia and China (as it was during the Cold War) have stood in resistance of any Western pressure against the Assad regime. On August 21, 2012, the Russian Foreign Minister Sergei Lavrov after meeting Chinese top diplomats warned the West against any unilateral action on Syria. ${ }^{52}$ This warning was re-iterated on May 14, 2013 when the Russian President, Vladimir Putin warned against "any measure that would further fuel the on-going crisis in Syria and destabilize the Arab country." ${ }^{53}$ This warning is an indictment against any foreign military intervention or the continued arming of Syrian rebels. Whatever the warning means however, the point to stress is its similarity to the antics of the Cold War. Russia, the heir of the Soviet Union, has taken a foreign policy stance which is diametrically opposed to the West. Russia's allies in this foreign policy posture are China, Iran, North Korea, Cuba, Venezuela, Bolivia, Ecuador and Nicaragua. Others include South Africa, Iraq, Algeria, Lebanon, Tanzania and Pakistan. It is interesting to note that besides South Africa, most of these states were aligned with the Soviet Union while the Cold War raged.

In addition to the foregoing, the Cold War years, witnessed increased negotiations between the Soviet Union and the United States. Some of these talks resulted to the Strategic Arms Limitation Talks (SALTs I and II). It is ironical that the year [1979] Soviet Union invaded Afghanistan was also the very year that SALT II was concluded.

Similarly, it becomes interesting to note that while the Syrian crisis lingers, the United States and Russia had agreed to work together towards finding a political solution to the crisis. This is the basis for the Geneva conference; it is a conference that is fraught with irreconcilable demands. The United States still looks for a regime change, something that Russia has continued to resist. Assad believes he can win the war militarily, while the opposition is holding out for more weapons possibly from the West. But should the removal of Assad be a pre-condition for the cessation of the Syrian crisis? ${ }^{54}$

\section{Conclusion}

The Arab awakening started in December 2010 in Tunisia. It gained an unprecedented momentum as it spread like wildfire to Egypt, Libya, Yemen, Bahrain and Syria. Notwithstanding its regional spread, the Arab uprising stemmed from similar popular demands for an end to authoritarian regimes and an enthronement of democratic reforms; it also called for guarantees to socio-economic opportunities. As a result of the sectarian diversities in these countries, the Arab Spring has led to different outcomes. In Tunisia, Egypt, Libya and Yemen, regime changes have been effected; some through the interventionist principle of the United Nations. But it is not so in Syria, where the superpower intrigues reminiscent of the Cold War is displayed.

The outbreak of the Syrian uprising actually challenged the status quo when it began to take the form and nature of conflicts associated to the Cold War. The superpower that had readily intervened in external conflicts had suddenly become feeble despite its will and power. It was this development that occasioned the need to assess the Syrian uprising and its semblance to the Cold War conflicts. As discovered in this study, many of the features of the Cold War world had been replicated in the Syrian conflict: vetoes and the threat of its use has once again hindered the United Nations from intervening in the conflict; arms race has ascended a feverish pitch; the search for allies has intensified the conflict; polarization is once again tearing the world apart and Russia aims at the status of Soviet Union. On the contrary, the West is still convinced that Russia's ambition of a superpower status remains an unachievable dream. These analysts insist that Russia's rapidly aging and unhealthy population, a declining birthrate and a stagnant, oil-dependent economy, is "a recipe for major instability" within the next two to three decades. ${ }^{55}$

Having considered these, Robert Fisk while commenting on William Hague's fear of likely resurgence of the Cold War over Iran's Nuclear crisis, asserts that "the new Cold War... which Hague was blathering on about has already started over Syria, not Iran..."56 McKay Peters aptly adds that "the so-called Arab Spring - of which the Syrian Civil war is part - is a far more complex event than credulous innocents in the West imagine. It's not simply uprisings by ground-down peasants against tyrants who repress them ...but about a continuation of the old, US-Russia standoff', ${ }^{57}$

This paper does not suggest a realist emergence of another Cold War. It rather calls for caution among the great powers, that should events continue in the direction to which they are already going, the world may be condemned to another Cold War with its ugly consequences of a third world war. 


\section{Notes}

[1]. Holliday, Joseph. "The Struggle for Syria" Institute for the Study of War. December, 2011, http://www.understandingwar.org/sites/default/files/Struggle_For_Syria.pdf Retrieved 23 Jan. 2014

[2]. Razzouk, Nayla; Alexander, Caroline (1 June 2011). "Syrian Thugs Assad's Tool in Crackdown, Groups Say". Bloomberg. Retrieved 23 Jan 2014

[3]. Gareth Smyth. "Lebanon drawn into Syria's Sectarian Conflict - Analysis" Tehran Bureau, Tuesday 21 January 2014. http://www.theguardian.com/world/iran-blog/2014/jan/21/lebanon-drawn-into-syrias-sectarian-conflict-analysis Retrieved 23 Jan $201^{4}$

[4]. Fisher, Max. 2013. "8 questions about Syria you were too embarrassed to ask" Washington Post, Tuesday, September 3

[5]. Abernethy, David B. 2000. The Dynamics of Global Dominance, New haven and London: Yale University Press, p.146

[6]. Kegley, C.W. Jr. 2007. World Politics: Trends and Transformation, Belmont: Thomson Wadsworth, p.557.

[7]. $\quad$ Holsti K.J. 1988. International Politics, $5^{\text {th }}$ ed. Englewood Cliffs, N.J.: Prentice Hall) p.423.

[8]. Alvin Z. Rubinstein. 1972. The Foreign Policy of the Soviet Union, New York: Random House, p.420.

[9]. Trentin, Massimiliano. "'The Pragmatic Politics of the Improvised Socialism': The East German Advisors in Syria, 1965-1972." In Trentin, M. and Gerlini, M. (eds.) The Middle East and the Cold War: Between Security and Development. Newcastle: Cambridge Scholars Publishing. 2012 pp. 79-104

[10]. "Foreign Relations of the Soviet Union." Wikipedia: The Free Encyclopedia. Wikimedia Foundation Inc. Sept. 15, 2013. http://en.wikipedia.org/wiki/Foreign_relations_of_the_Soviet_Union Accessed Nov. 13, 2013

[11]. Legvold, Robert. "Cold War." Microsoft Encarta 2009 [DVD]. Redmond, WA: Microsoft Corporation, 2008

[12]. "Foreign Relations of the Soviet Union." Wikipedia: The Free Encyclopedia.

[13]. Sharnoff, M. "The Syria-Soviet Alliance" Infocus Quarterly. 3(1) 2009 http://www.jewishpolicycenter.org/833/the-syria-sovietalliance Accessed Nov. 13, 2013

[14]. Murrin, J.M., et al. Liberty, Equality, Power: A History of the American People (Concise Third Edition). Belmont, California: Wadsworth/Thomson Learning. 2004. pp. 834-835

[15]. Sharp, J.M. and Blanchard, C.M. "Syria: Unrest and U.S. Policy" Congressional Research Service. May 24, 2012 p. 9

[16]. Jones, Dow. "Interview with Syrian President Bashar al-Assad" Wall Street Journal January 31, 2011 http://online.wsj.com/article/SB10001424052748703833204576114712441122894.html June 23, 2012

[17]. Sterling, J. "Daraa: the Spark that lit the Syrian Flame" CNN March 1, 2012 http://edition.cnn.com/2012/03/01/world/meast/syriacrisis-beginnings/index.html August 26, 2012

[18]. Abouzeid, Rania. "How Graffiti Stirred an Uprising" TIME. March $22, \quad 2011$. http://www.time.com/time/world/article/0,8599,2060788,00.html August 26, 2012

[19]. Sharp, Jeremy M. "Unrest in Syria and U.S. Sanctions against the Assad Regime" Congressional Research Service. August 9, 2011 p. 3

[20]. Sharp, Jeremy M. and Blanchard, Christopher M., May 24, 2012 p. 11

[21]. Dekel, Udi and Perlov, Orit. “The Syrian Uprising: Syrian Discourse on the Social Networks.” INSS Insight No. 341, June 2012

[22]. "Syria Crisis: March was 'Conflicts' Deadliest Month” BBC News. April 1, 2013

[23]. Jadaliyya Reports. "Burhan Ghalioun Address to the Syrian People (Video and Translated Transcript" Jadaliyya. November 6, 2011 http://www.jadaliyya.com/pages/index/3070/burhan-ghalioun-address-to-the-syrian-people-(vide August 3, 2012.

[24]. Flemes, Daniel. "Conceptualizing Regional Power in International Relations: Lessons from the South African Case" GIGA Research Programme: Power, Violence and Security. Working Paper 53, 2007 p. 7

[25]. Jim Nichol, Coordinator. "Russian Political, Economic, and Security Issues and U.S. Interests" Congressional Research Service. Sept. 13, 2013. p. 30

[26]. Jim Nichol, Coordinator. Sept. 13, 2013.

[27]. "Economy of Russia." Wikipedia: The Free Encyclopedia. Wikimedia Foundation Inc. Dec. 15, 2013. http://en.wikipedia.org/wiki/ecconomy_of_Russia Accessed Nov. 13, 2013

[28]. Jim Nichol, Coordinator. Sept. 13, 2013.

[29]. Carolina, Pallin. "Russian Military Capability today" in Carolina Pallin (ed.) Russian Military Capability in a Ten-Year Perspective -2011. Moscow: Ministry of Defense. 2012 pp. $15-21$.

[30]. Lieber, Kier. "The New Era of Nuclear Weapons, Deterrence and Conflict" Strategic Studies Quarterly. Spring 2013. p. 4

[31]. Lorber, Janie. "The Early Word: New START Treaty Signed" New York Times. April 8, 2010. http://thecausus.blogs.nytimes.com/2010/04/08/the-early-word-new-start-treaty-signed/?_php=true\&_type=blogs\&_r=0 Accessed Nov. 13, 2013

[32]. Carolina, Pallin. 2012 p. 21

[33]. Brooke, James. "Russia's Military Might for More Than Show" Voice of America. May 9, 2013. http://www.voanews.com/content/russia-kremlin-moscow-red-square-military-parade/1657829.html Accessed October 17, 2013.

[34]. Nye, Joseph S. Jr. "Soft Power" Foreign Policy. No. 80, 1990. pp. 153-171

[35]. Tsykangov, Andrei. "If Not by Tanks, then by Banks? The Role of Soft Power in Putin's Foreign Policy" Europe-Asia Studies. 2006, 58(7) pp. 1079-1099

[36]. Anderson, Jed. "The Rise of Russian Soft Power" Over the Edge. Oct. 9, 2013. file://C:/Users/AKACHUKWU/Desktop/The\%20rise\%20of\%20Russian\%20soft \%20power\%20_\%20Over\%20The\%20Edge\%20N ewspaper.htm Accessed November 3, 2013.

[37]. Jarosław Ćwiek-Karpowicz. "Limits to Russian Soft Power in the Post-Soviet Area" Deutsche Gesellschaft fur Auswartige Politik. Vol. 8, July 2012.

[38]. Alicja Curanović. “The Religious Diplomacy of the Russian Federation” Russie.Nei.Reports June, 2012. No. 12.

[39]. Lopez, G.A. "Russia and China: Sabotaging UN with Vetoes" CNN. February $8, \quad 2012$ http://edition.cnn.com/2012/02/08/opinion/lopez-russia-sanctions-cold-war/index.html August 28, 2012

[40]. Nichols, Michelle. "Russia, China Veto U.N. Security Council resolution on Syria" Reuters. July 19, 2012 http://www.reuters.com/article/idUSBRE86I0UD20120720?irpc=932 Accessed November 4, 2013

[41]. "Putin warns West not to Underestimate Russia's Military Might" YaLibnan. December $12,2013$. http://www.yalibnan.com/2013/12/12/putin-warns-west-not-to-underestimate-russias-military-might/ Accessed December 13, 2013.

[42]. Katz, Mark N., "The Moscow-Damascus Alliance: A Tangled Tale" CNN, May 28,2012 http://edition.cnn.com/2012/02/09/opinion/russia-syria-relations Accessed January 31, 2013.

[43]. Zvi, Bar'el. 2013. "The Syria crisis: A throwback to the Cold War", Harretz, Sep. 17. 
[44]. Zvi, Bar'el. 2013.

[45]. "Exports Act of 1949" Oxford Reference: Oxford Essential Dictionary of the U.S Military. http://www.oxfordreference.com/view/10.1093/oi/authority.20110803095805557 Accessed Nov. 14, 2013.

[46]. Legvold, Robert. "Cold War." Microsoft Encarta 2009 [DVD]. Redmond, WA: Microsoft Corporation, 2008

[47]. Sharp, J.M. and Blanchard, C.M. "Armed Conflict in Syria: U.S. and International Response” Congressional Research Service. April 2013.p. 40

[48]. George Crile. Charlie Wilson's War: The Extraordinary Story of How the Wildest Man in Congress and a Rogue CIA Agent Changed the History of Our Times. New York: Grove Press. 2007: Preface.

[49]. Landler, M., Gordon, M., Barnard, A. "U.S. Will Grant Recognition to Syrian Rebels, Obama Says" New York Times. December 11, 2012. http://www.nytimes.com/2012/12/12/world/middleeast/united-states-involvement-in-syria.html?pagewanted=all\&_r=0 Accessed May 14, 2013.

[50]. Pierce Willans June 4, 2013 Wired Magazine Bashar Al-Assad: Syria's Civil War Is Becoming a Cold War-Style Proxy Battle.

[51]. "Friends of Syria Group" Wikipedia April 21, 2013. http://en.wikipedia.org/wiki/Friends_of_Syria_Group Accessed May 14, 2013

[52]. Dominic Evans. "Russia warns West over Syria after Obama Threats" Reuters. August 21 , 2012. http://www.reuters.com/article/2012/08/21/us-syria-crisis-idUSBRE8610SH20120821 Accessed May 14, 2013.

[53]. "Putin warns against actions fuelling crisis in Syria." PressTV. May 14 , 2013. http://www.presstv.com/detail/2013/05/14/303483/russia-warns-against-moves-over-syria/ Accessed May 14, 2013.

[54]. Some Western analysts like Barry Pavel hold the view that Russia's dream of a superpower is unachievable. Mr Pavel is a director of the Brent Scowcroft Center for International Security at the Atlantic Council. Pavel insists that the Cold War is "one-sided" because "the other side [the United States] could not care less about Russia as a military threat.

[55]. Gordon, Michael R. "U.S. Fears Russia May Sell Air-Defense System to Syria" New York Times. May 8, 2013. http://www.nytimes.com/2013/05/09/world/middleeast/us-fears-russia-may-sell-air-defenses-to-syria.html Accessed May 14, 2013.

[56]. Fisk, Robert. "The New Cold War has already Started - in Syria" The Independent. February 25 , 2012. http://www.independent.co.uk/voices/commentators/fisk/robert-fisk-the-new-cold-war-has-already-started--in-syria-7440620.html Accessed May 15, 2013

[57]. McKay, Peter. "Syria's Dead are Victims of the New Cold War" Daily Mail June 12 , 2012. http://www.dailymail.co.uk/debate/article-2157318/Syrias-dead-victims-new-Cold-War.html Accessed January 21, 2013 